\title{
Tinjauan atas artikel penelitian dan pengembangan pendidikan di Jurnal Keolahragaan
}

\author{
Hysa Ardiyanto *, Syarief Fajaruddin \\ Universitas Negeri Yogyakarta. Jalan Colombo No. 1, Karangmalang, Yogyakarta 55281, Indonesia \\ * Corresponding Author. E-mail: hysaardiyanto@gmail.com \\ Received: 25 May 2019; Revised: 29 July 2019; Accepted: 1 August 2019
}

\begin{abstract}
Abstrak
Relevansi penelitian pendidikan dengan praktik pendidikan masih sering dipandang secara skeptis. Padahal ada jenis penelitian yang dinilai berpotensi menjembatani jurang tersebut, yaitu penelitian dan pengembangan pendidikan. Tampilan kata kunci yang paling banyak digunakan di Jurnal Keolahragaan menunjukkan jenis penelitian ini banyak dipublikasikan. Namun demikian, tinjauan pada artikel yang melaporkan hasil penelitian ini belum dilakukan. Oleh karena itu, studi ini menganalisis artikel-artikel penelitian dan pengembangan di Jurnal Keolahragaan. Metode yang digunakan dalam penelitian ini adalah studi dokumen. Data dikumpulkan melalui penelusuran arsip di situs web Jurnal Keolahragaan. Hasilnya, metode penelitian dan pengembangan memang banyak digunakan dan dilaporkan di jurnal tersebut. Analisis dokumen berupa sampel artikel terpilih menghasilkan temuan berupa: penggunaan istilah 'model' yang dapat diperdebatkan, kekurangakuratan dalam penyajian referensi prosedur pengembangan dan prosedur evaluasi yang cenderung pada data-data kuantitatif.
\end{abstract}

Kata Kunci: Jurnal Keolahragaan; penelitian dan pengembangan; studi dokumen

\section{A review of the educational research and development articles in Jurnal Keolahragaan}

\begin{abstract}
Skeptical feelings about the value of educational research remained. Educational research and development $(R \& D)$ as applied research has the potential to bridges the gap between educational research and practice. The keywords tag cloud in the Jurnal Keolahragaan revealed that this type of research is widely conducted. Unfortunately, a review of the $R \& D$ articles in this journal had not been carried out. Therefore, this study aims to review $R \& D$ articles in Jurnal Keolahragaan. The method used in this research is a document study. Data collected from the journal archive. The result of this study confirmed that $R \& D$ was indeed widely used and reported in the journal. The findings from analytical reviews were as follow: the debatable use of the term 'model' which is frequently used, the inaccuracy of the reference used in developmental procedures, and the evaluation procedures dominated by quantitative data.
\end{abstract}

Keywords: document study; Jurnal Keolahragaan; research and development

How to Cite: Ardiyanto, H., \& Fajaruddin, S. (2019). Tinjauan atas artikel penelitian dan pengembangan pendidikan di Jurnal Keolahragaan. Jurnal Keolahragaan, 7(1), 83-93. doi:https://doi.org/10.21831/jk.v7i1.26394

do https://doi.org/10.21831/jk.v7i1.26394

\section{PENDAHULUAN}

Pelaksanaan pendidikan kesehatan berbasis riset di sekolah dinilai masih dalam tahap awal dan membutuhkan pengembangan lebih lanjut (Wijayanti \& Wibowo, 2017). Isu mengenai permasalahan penelitian lebih mengemuka di tingkat pendidikan yang lebih tinggi. Hasil studi Noor (2010) tentang implementasi kebijakan program penelitian pada perguruan tinggi menunjukkan adanya kendala yang disebabkan oleh masih rendahnya kemampuan metodologi. Jika menengok ke lingkup institusi, Universitas Negeri Yogyakarta misalnya, sejak tahun 2016 terjadi kecenderungan peningkatan skor penelitian dan skor publikasi ilmiah oleh 92 dosen yang menjadi partisipan studi tersebut. Meskipun temuan ini menggembirakan, namun pemberian pelatihan tentang metodologi penelitian dan/atau cara menulis artikel yang layak dipublikasikan tetap menjadi saran yang direkomendasikan (Darmalaksana, 2017; Retnowati, Mardapi, \& Kartowagiran, 2018). Penulisan karya ilmiah pun 
disadari sebagai keterampilan penting yang harus dimiliki oleh para akademisi (Aisyah \& Mahanani, 2017).

Dalam menyoroti lemahnya literasi bidang keolahragaan, Winarno (2018) menilai hal tersebut disebabkan oleh rendahnya produktivitas karya bidang keolahragaan. Masalah ini berkaitan dengan terbatasnya referensi bidang keolahragaan di Indonesia, kurangnya budaya baca tulis stakeholder keolahragaan dan budaya prestasi olahraga yang dominan berwujud performa fisik, sehingga menulis karya masih menjadi masalah. Sarannya adalah mengubah budaya: prestasi olahraga berupa performa fisik perlu dokumentasikan serta ditulis sebagai karya akademik.

Salah satu bentuk karya akademik adalah artikel yang dipublikasikan dalam prosiding maupun jurnal ilmiah. Jurnal yang terkemuka dapat menjadi cerminan kondisi komunitas ilmuwan di suatu bidang. Saat ini, peringkat terbaik jurnal ilmiah bidang ilmu keolahragaan di Science and Technology Index (SINTA) Kementerian Riset, Teknologi, dan Pendidikan Tinggi Republik Indonesia (Kemenristekdikti) adalah peringkat dua. Jurnal Keolahragaan merupakan salah satu jurnal yang menempati posisi tersebut. Fokus dan cakupannya meliputi aspek ilmu keolahragaan seperti pendidikan jasmani, kepelatihan olahraga dan kesehatan olahraga. Dalam tampilan keywords tag cloud di Jurnal Keolahragaan, muncul kata 'model' dan 'pengembangan' sebagai kata kunci yang paling banyak digunakan. Temuan awal ini dapat dijadikan asumsi bahwa penelitian dan pengembangan merupakan metode yang banyak digunakan pada penelitian di bidang ilmu keolahragaan.

Penelitian dan pengembangan, yang berbasis pada praktik di dunia industri, berpotensi besar diterapkan di dunia pendidikan karena dapat menjembatani antara penelitian pendidikan dan praktik pendidikan (Borg \& Gall, 1983; Gall, Gall, \& Borg, 2003). Jenis penelitian ini dapat dikategorikan sebagai penelitian terapan. Dalam testimoninya saat mengenang kepergian Borg, Gall (1991) mengungkapkan keyakinan Borg pada kekuatan jenis penelitian ini untuk meningkatkan kualitas pendidikan. Kini, sekitar tiga dekade sejak gagasan itu dikemukakan, penelitian dan pengembangan pendidikan telah banyak dipraktikkan dan menghasilkan berbagai produk. Namun demikian, jurang antara penelitian dan praktik pendidikan diakui masih menganga. Hasil studi Vanderlinde dan van Braak (2010) menunjukkan skeptisisme guru pada nilai kegunaan penelitian pendidikan dan relevansinya dengan praktik pendidikan. Peran penelitian dan pengembangan sebagai jembatan menjadi semakin penting.

Kembali ke pembahasan mengenai Jurnal Keolahragaan. Munculnya kata 'model' dan 'pengembangan' sebagai kata kunci yang paling banyak digunakan mengindikasikan kepopuleran penelitian dan pengembangan jika dibandingkan dengan jenis penelitian lain. Aspek pembahasan yang sudah banyak diketahui dari penelitian dan pengembangan adalah publikasi hasil-hasil pengembangannya dan teori atau panduan melalui buku yang saat ini beredar, contohnya karya Setyosari (2013); Sutarti dan Irawan (2017) serta artikel jurnal seperti yang disajikan oleh Haryati (2012). Sementara itu, studi yang memotret penelitian dan pengembangan pendidikan di Indonesia belum diketahui. Oleh karena itu, studi ini dilakukan dengan tujuan untuk mengetahui gambaran hasil penelitian dan pengembangan yang telah dilakukan di bidang keolahragaan melalui tinjauan analitis terhadap artikel-artikel di Jurnal Keolahragaan.

Untuk mencapai tujuan dalam penelitian ini, analisis dipandu oleh tiga pertanyaan, yaitu: (1) Bagaimana posisi penelitian dan pengembangan dibandingkan dengan jenis penelitian lain dalam hal kuantitas artikel yang dipublikasikan? (2) Apa saja jenis-jenis pengembangan yang telah dihasilkan dan dilaporkan? (3) Apa saja isu-isu yang ditemukan melalui analisis terhadap artikel penelitian dan pengembangan di Jurnal Keolahragaan?

\section{METODE}

Studi dokumen digunakan dalam penelitian ini. Studi dokumen banyak dimanfaatkan pada penelitian kualitatif karena merupakan sumber yang stabil, sifatnya alamiah, berguna sebagai bukti suatu pengujian dan hasilnya dapat membuka pemahaman terhadap sesuatu yang diselidiki (Moleong, 2007). Data dalam studi dokumen dikumpulkan dengan cara menghimpun dan menganalisis dokumen-dokumen, baik dokumen tertulis, gambar, hasil karya, maupun elektronik dan hasil yang dilaporkan berupa analisis terhadap dokumen-dokumen tersebut (Nilamsari, 2014). Dokumen dalam penelitian ini adalah artikel-artikel laporan hasil penelitian dan pengembangan yang telah dipublikasikan di Jurnal Keolahragaan.

Data dikumpulkan melalui penelusuran arsip di situs web Jurnal Keolahragaan (https://journal.uny.ac.id/index.php/jolahraga/iss ue/archive). Tahun publikasi artikel tidak diba- 
tasi, yaitu sejak jurnal tersebut diterbitkan sampai dengan edisi terakhir saat penelitian ini dilakukan (April 2013-September 2018). Langkah pertama dalam tahap ini adalah mengidentifikasi judul artikel di setiap volume dan nomor penerbitan. Instrumen yang digunakan adalah lembar daftar periksa (checklist). Dengan melakukan verifikasi pada abstrak, judul-judul artikel yang merupakan hasil penelitian dan pengembangan ditandai. Langkah ini menghasilkan daftar judul artikel penelitian dan pengembangan yang masih umum. Artinya, judul-judul artikel belum dibedakan antara penelitian dan pengembangan dalam konteks pendidikan dan non-pendidikan. Langkah selanjutnya, judul artikel penelitian dan pengembangan yang sudah terjaring kemudian diseleksi untuk menentukan judul artikel penelitian dan pengembangan pendidikan. Kriteria seleksi yang digunakan dalam studi ini adalah berdasarkan subjek penelitian, jika judul dan abstrak tidak secara eksplisit menunjukkan siswa sekolah sebagai subjek penelitiannya, maka akan dieksklusikan. Dari seleksi ini didapatkan daftar judul artikel penelitian dan pengembangan pendidikan yang akan diproses pada tahap selanjutnya.

Judul artikel penelitian dan pengembangan pendidikan yang telah terseleksi kemudian diidentifikasi jenis hasil pengembangannya lalu dikelompokkan. Dari pengelompokan ini dihasilkan sebaran jumlah artikel di setiap kategori jenis hasil pengembangan. Analisis lebih lanjut dilakukan dengan mengambil sampel artikel penuh dari kategori jenis hasil pengembangan yang paling banyak muncul. Artikel-artikel yang terseleksi pada tahap ini digunakan sebagai basis untuk melakukan analisis sehingga menghasilkan tematema yang disajikan pada bagian pembahasan.

\section{HASIL DAN PEMBAHASAN}

Pengumpulan data menghasilkan informasi jumlah artikel penelitian dan pengembangan di Jurnal Keolahragaan. Dari total 116 judul artikel yang sudah dipublikasikan, 56 judul $(48 \%)$ diantaranya merupakan artikel hasil penelitian dan pengembangan. Data ini membuktikan asumsi awal yang menyatakan bahwa penelitian dan pengembangan merupakan jenis penelitian yang banyak dilakukan di bidang ilmu keolahragaan. Jumlah artikel penelitian dan pengembangan beserta sebaran tahun publikasinya di Jurnal Keolahragaan dapat dilihat pada Tabel 1.

Pada tahun pertama penerbitan, empat dari 16 artikel (25\%) yang diterbitkan merupakan artikel penelitian dan pengembangan. Tahun pertama penerbitan Jurnal Keolahragaan memiliki persentase artikel penelitian dan pengembangan terkecil. Pada tahun berikutnya persentase tersebut melonjak menjadi yang tertinggi. Tercatat 70\% artikel yang diterbitkan pada tahun 2014 adalah artikel penelitian dan pengembangan. Bahkan pada volume 2 nomor 1 tahun 2014, sebanyak $80 \%$ artikel pada edisi tersebut merupakan artikel penelitian dan pengembangan. Jumlah artikel penelitian dan pengembangan yang dipublikasikan oleh Jurnal Keolahragaan sempat turun secara berturut-turut pada dua tahun berikutnya, namun kembali naik pada tahun 2017. Di tahun berikutnya, artikel penelitian dan pengembangan masih menguasai $30 \%$ porsi jumlah artikel yang diterbitkan.

Tabel 1. Jumlah Artikel Penelitian dan Pengembangan di Jurnal Keolahragaan

\begin{tabular}{ccc}
\hline $\begin{array}{c}\text { Volume } \\
\text { Nomor), } \\
\text { Tahun }\end{array}$ & $\begin{array}{c}\text { Jumlah } \\
\text { Artikel yang } \\
\text { Diterbitkan }\end{array}$ & $\begin{array}{c}\text { Jumlah Artikel } \\
\text { Penelitian dan } \\
\text { Pengembangan }\end{array}$ \\
\hline $1(1), 2013$ & 8 & 1 \\
$1(2), 2013$ & 8 & 3 \\
$2(1), 2014$ & 10 & 8 \\
$2(2), 2014$ & 10 & 6 \\
$3(1), 2015$ & 10 & 5 \\
$3(2), 2015$ & 10 & 7 \\
$4(1), 2016$ & 10 & 6 \\
$4(2), 2016$ & 10 & 3 \\
5 (1), 2017 & 10 & $6 *$ \\
5 (2), 2017 & 10 & 5 \\
6 (1), 2018 & 10 & 3 \\
$6(2), 2018$ & 10 & 3 \\
Jumlah & 116 & 56 \\
\hline *alah satunya berstatus retracted
\end{tabular}

*salah satunya berstatus retracted.

Jumlah artikel penelitian dan pengembangan yang hampir mencapai setengah dari keseluruhan jumlah artikel di Jurnal Keolahragaan menunjukkan gejala yang bertolak belakang dengan pandangan Borg dan Gall di tahun 1983 sampai dua dekade kemudian. Bagi peneliti yang berstatus mahasiswa, "It is highly unlikely that a graduate student will be able to find the financial and personnel support to complete a major $R$ \& $D$ project" (Borg \& Gall, 1983; Gall et al., 2003). Saat melakukan penelitian dan pengembangan yang besar (major), isu yang perlu dipertimbangkan oleh peneliti adalah persoalan dukungan finansial dan personel. Jika dilihat dari afiliasi institusi para penulis pertama artikel penelitian dan pengembangan di Jurnal Keolahragaan, mereka berasal dari universitas. Apakah temuan ini menunjukkan isu-isu yang dianggap sebagai keterbatasan dalam melakukan penelitian dan pengembangan pendidikan sudah relatif dapat teratasi? Media instruksional yang dianggap 
mahal dan perlu dihindari saat pernyataan tersebut pertama kali dikemukakan adalah $16 \mathrm{~mm}$ film dan synchronized slidetape.

Generasi pengguna media instruksional pembelajaran masa kini bahkan tidak lagi mengenal benda-benda tersebut. Saat ini pembuatan media instruksional dalam format audio visual atau multimedia bukan lagi hal yang dianggap mahal. Teknologi telah memudahkan pengembangan media pembelajaran, tetapi penggunaan media dan teknologi secara efektif masih tergantung pada desain instruksional yang baik serta pelatihan dan dukungan bagi mereka yang menggunakan teknologi tersebut (Spector, 2017). Temuan ini juga berbanding terbalik dengan anggapan Tegeh, Jampel, dan Pudjawan (2015) yang melihat kurangnya materi perkuliahan metodologi penelitian dan pengembangan serta langkanya buku yang membahas model-model penelitian pengembangan di Indonesia. Keterbatasan literatur ternyata tidak menurunkan popularitas metode penelitian dan pengembangan.

Pembahasan berikutnya dari hasil pengumpulan data adalah pembagian kategori penelitian dan pengembangan yang dilakukan dalam pendidikan dan di luar lingkungan pendidikan. Jumlah artikel penelitian dan pengembangan yang dilakukan di sekolah dan di luar sekolah menunjukkan proporsi yang seimbang. Dari 56 artikel penelitian dan pengembangan, 28 artikel (50\%) dalam judul dan atau abstraknya menyebutkan penelitian dilakukan pada siswa sekolah. Jenjang pendidikan siswa yang menjadi subjek penelitian mulai TK hingga SMA. Penelitian dengan subjek siswa SD menempati jumlah terbanyak dengan 14 artikel (50\%) diikuti siswa TK dengan 6 artikel (21\%), SMP 5 artikel $(5,18 \%)$ dan SMA/SMK 3 artikel $(3,12 \%)$. Penelitian pada siswa SD menempati porsi terbesar karena satuan pendidikan ini memiliki jumlah unit sekolah terbanyak jika dibandingkan dengan jenis satuan pendidikan formal lainnya pada jenjang dasar dan menengah. Berdasarkan Data Master Satuan Pendidikan Dasar dan Menengah, jumlah sekolah SD/Sederajat mencapai 174.606 sekolah. Jumlah ini jauh lebih banyak jika dibandingkan dengan jumlah SMP/Sederajat sebanyak 58.201 sekolah, SMA/Sederajat 22.615 sekolah dan SMK/Sederajat 14.214 sekolah (Kementerian Pendidikan dan Kebudayaan, n.d.).

Berdasarkan jenis pengembangannya, artikel yang termasuk dalam penelitian dan pengembangan pendidikan dapat dikelompokkan ke dalam lima kategori. Dari 28 judul artikel, Pengembangan Model Pembelajaran menempati porsi terbanyak dengan 12 artikel (43\%), disusul Pengembangan Model Permainan atau Aktivitas berjumlah 9 artikel (32\%), kemudian Pengembangan Media Pembelajaran sebanyak 4 artikel (14\%), Pengembangan Modul Pembelajaran ada 2 artikel (7\%), dan terdapat 1 artikel (4\%) Pengembangan Alat untuk pembelajaran. Hasil selengkapnya dapat dilihat pada Tabel 2.

Langkah selanjutnya, peneliti mengambil sampel artikel penuh sebagai basis untuk melakukan analisis. Sampel dipilih, pertamatama, mewakili tahun publikasi untuk mendapatkan gambaran perkembangan penelitian dan pengembangan dari tahun ke tahun. Kriteria pemilihan berikutnya adalah keterwakilan jenis satuan pendidikan subjek penelitiannya. Artikel tahun 2017 otomatis terpilih karena merupakan satu-satunya artikel Pengembangan Model Pembelajaran pada tahun tersebut. Di tahun 2016 terdapat dua artikel dengan dua jenis subjek yang berbeda, yaitu siswa TK dan siswa SMP. Untuk memilih diantara dua artikel tersebut, peneliti terlebih dahulu beralih ke artikel tahun 2014. Artikel dengan subjek siswa TK bisa dianggap sebagai sampel yang unik diantara ketiga artikel pada tahun tersebut. Untuk itu sampel yang dipilih mewakili tahun 2014 adalah artikel dengan subjek siswa TK, sementara tahun 2016 diwakili oleh artikel dengan subjek siswa SMP. Artikel tahun 2015 dan 2013 menyisakan hanya subjek siswa SD. Sampel dari tahun 2015 dipilih dari siswa SD kelas bawah karena siswa SD kelas atas telah diwakili oleh artikel tahun 2017. Sementara itu artikel tahun 2013 dipilih untuk melengkapi keterwakilan tahun dengan mempertimbangkan materi pengembangannya. Bola voli tidak dipilih karena materi permainan dianggap telah terwakili oleh tenis meja.

Kelima sampel yang telah terpilih kemudian dianalisis pada bagian judul, metode penelitian dan hasil pengembangannya. Data diperoleh dari sampel dengan cara menyalin secara langsung kalimat di dalam artikel yang dianalisis. Tabel 3 menunjukkan data sampel artikel yang dianalisis. Pembahasan dari hasil analisis ini disajikan dalam tiga tema seperti dapat dilihat pada bagian berikutnya.

\section{Penggunaan Kata 'Model' yang Dapat Diperdebatkan}

Seluruh artikel yang dianalisis menggunakan kata 'model' di judul dan atau di abstrak. Artikel "Gerak Multilateral ..." tidak mencantumkan kata 'model' dalam judul, namun pada kalimat pertama abstrak menyebutkan, 
"Penelitian ini bertujuan menghasikan model pembelajaran..." Penggunaan kata 'model' dalam judul dan abstrak dapat dinilai sebagai upaya untuk menunjukkan tujuan atau sesuatu yang ingin dihasilkan dari penelitian dan pengembangan. Namun demikian, tujuan ini menjadi kabur karena hasil-hasil dari pengembangan adalah produk. Seluruh artikel yang dianalisis melaporkan dalam hasil penelitian berupa buku panduan atau buku pedoman. Antara model dan produk dapat dilihat adanya perbedaan.

Meskipun 'model' dapat diartikan sebagai suatu contoh yang sangat baik sehingga bisa ditiru, "something that a copy can be based on because it is an extremely good example of its type" (Walter, 2008), namun penggunaan kata 'model' dalam sebuah artikel jurnal ilmiah bisa jadi rancu dengan konsep 'model' yang telah dipakai dan disepakati penggunaannya dalam bahasa sains. Istilah 'model' dalam pembahasan ilmiah digunakan untuk gambar, skema, grafik atau bentuk lain yang merupakan abstraksi dari suatu fenomena. Model hanya menampilkan komponen-komponen yang dianggap sebagai kunci dengan mengabaikan komponen-komponen lain dari yang kompleks dalam fenomena sesungguhnya. Menurut Cohen, Manion, dan Morrison (2007), kata 'model' sering kali dipertukarkan dengan teori. Keduanya dapat dilihat sebagai perangkat penjelas atau skema yang memiliki kerangka kerja konseptual untuk memberikan representasi dari fenomena tertentu. Pada umumnya model digunakan untuk menjelaskan fenomena dalam ilmu pengetahuan (Bokulich, 2011).

Tabel 2. Pengelompokan Jenis Pengembangan Bidang Pendidikan di Jurnal Keolahragaan

\begin{tabular}{|c|c|c|c|}
\hline Jenis pengembangan & Materi & Subjek & Edisi \\
\hline Pengembangan Model & Teknik dasar tenis meja & Siswa SD kelas atas & $2017,5(2)$ \\
\hline \multirow[t]{11}{*}{ Pembelajaran } & Motorik kasar & Siswa TK kelompok A & $2016,4(2)$ \\
\hline & Integratif (atletik dengan biologi) & Siswa SMP & $2016,4(1)$ \\
\hline & Lempar lembing & Siswa SMP & $2015,3(2)$ \\
\hline & Integratif berbasis aktivitas jasmani & Siswa TK & $2015,3(2)$ \\
\hline & Gerak multiateral (melalui bola besar) & Siswa SD kelas bawah & $2015,3(2)$ \\
\hline & Bola basket & Siswa SD kelas atas & $2015,3(1)$ \\
\hline & Motorik (menggunakan agility ladder) & Siswa SD & $2014,2(2)$ \\
\hline & Pengenalan air & Siswa TK & $2014,2(2)$ \\
\hline & $\begin{array}{l}\text { Motorik (modifikasi permainan } \\
\text { tradisional) }\end{array}$ & Siswa SD kelas atas & $2014,2(1)$ \\
\hline & Bola voli & Siswa SD kelas atas & $2013,1(2)$ \\
\hline & Penjas (melalui permainan) & Siswa SD & $2013,1(2)$ \\
\hline Pengembangan Model & Permainan tradisional & Siswa SD kelas atas & $2017,5(2)$ \\
\hline \multirow[t]{8}{*}{ Permainan/Aktivitas } & Perseptual motorik dan perilaku sosial & Siswa SD kelas bawah & $2017,5(2)$ \\
\hline & Sepak takraw & Siswa SD kelas atas & $2017,5(1)$ \\
\hline & Teknik dasar bola basket & Siswa SMP & $2017,5(1)$ \\
\hline & Tarian bonet & Siswa SD & $2017,5(1)$ \\
\hline & Bola tangan & Siswa SD kelas atas & $2016,4(1)$ \\
\hline & Lompat jauh (pengenalan) & Siswa SD kelas atas & $2015,3(2)$ \\
\hline & Tematik integratif & Siswa TK & $2014,2(2)$ \\
\hline & Senam Si Buyung & Siswa TK & $2013,1(2)$ \\
\hline Pengembangan Media & Budaya hidup sehat (multimedia) & Siswa SMA & $2014,2(1)$ \\
\hline \multirow[t]{3}{*}{ Pembelajaran } & Penjasorkes (komputer) & Siswa SMA & $2014,2(1)$ \\
\hline & Tenis lapangan (VCD) & Siswa SD & $2013,1(2)$ \\
\hline & Teknik dasar bola voli & Siswa SMP & $2013,1(1)$ \\
\hline Pengembangan Modul & Pencak silat & Siswa SMK & $2018,6(2)$ \\
\hline Pembelajaran & Perilaku hidup bersih dan sehat & Siswa TK & $2017,5(1)$ \\
\hline Pengembangan Alat & Target net bulu tangkis & Siswa SMP & $2015,3(1)$ \\
\hline
\end{tabular}


Tabel 3. Sampel Artikel Pengembangan Model Pembelajaran yang Dianalisis

\begin{tabular}{|c|c|c|}
\hline Judul (Tahun) & Metode Penelitian & Hasil Pengembangan \\
\hline $\begin{array}{l}\text { Pengembangan Model } \\
\text { Pembelajaran Pengenalan } \\
\text { Teknik Dasar Tenis Meja } \\
\text { untuk Siswa SD Kelas } \\
\text { Atas (Purwanto \& } \\
\text { Suharjana, 2017) }\end{array}$ & $\begin{array}{l}\text { Penelitian ini mengadopsi dari tahapan } \\
\text { pengembangan yang dikemukakan } \\
\text { oleh (Gall, Gall, \& Borg, 2007a, p. } \\
\text { 569). Pada penelitian dan } \\
\text { pengembangan ini, tahapan } \\
\text { dimodifikasi (disederhanakan) } \\
\text { menjadi } 2 \text { tahap yaitu... }\end{array}$ & $\begin{array}{l}\text { Hasil penelitian berupa } \\
\text { pengembangan model pembelajaran } \\
\text { pengenalan teknik dasar tenis meja } \\
\text { terdiri atas:... Model disusun dalam } \\
\text { buku panduan berjudul } \\
\text { "pengembangan model pembelajaran } \\
\text { pengenalan teknik dasar tenis meja } \\
\text { siswa SD kelas atas". }\end{array}$ \\
\hline $\begin{array}{l}\text { Model Pembelajaran } \\
\text { Integratif Penjasorkes } \\
\text { Materi Atletik dengan } \\
\text { Pendidikan IPA Materi } \\
\text { Biologi untuk Siswa SMP } \\
\text { (Fitri \& Winarni, 2016) } \\
\end{array}$ & $\begin{array}{l}\text {...mengikuti sepuluh langkah } \\
\text { pelaksanaan penelitian (Gall et al., } \\
\text { 2003, p. } 784 \text { ) dengan penyederhanaan. } \\
\text { Langkah yang ditempuh:... }\end{array}$ & $\begin{array}{l}\text { Hasil penelitian ini berupa buku } \\
\text { panduan yang berisikan syntax } \\
\text { (langkah-langkah), bentuk penilaian, } 6 \\
\text { permainan integratif, dan rencana } \\
\text { pelaksanaan pembelajaran yang layak } \\
\text { dan efektif. }\end{array}$ \\
\hline $\begin{array}{l}\text { Gerak Multilateral melalui } \\
\text { Permainan Bola Besar } \\
\text { untuk Anak SD Kelas } \\
\text { Bawah (Wibawa \& } \\
\text { Sugiyanto, 2015) }\end{array}$ & $\begin{array}{l}\text { Jenis penelitian ini adalah penelitian } \\
\text { dan pengembangan yang } \\
\text { mengadaptasikan langkah- langkah } \\
\text { pengembangan pendidikan oleh (Gall, } \\
\text { Gall, \& Borg, 2007b, p. 590). }\end{array}$ & $\begin{array}{l}\text { Hasil penelitian berupa } \\
\text { pengembangan model pembelajaran } \\
\text { gerak multilateral melalui permainan } \\
\text { bola besar yang terdiri atas sembilan } \\
\text { permainan, yaitu:... Pengembangan } \\
\text { model pembelajaran gerak multilateral } \\
\text { disusun dalam buku pedoman } \\
\text { pembelajaran dan CD dengan judul } \\
\text { "Bola Multi Gerak". }\end{array}$ \\
\hline $\begin{array}{l}\text { Model Pengenalan Air } \\
\text { bagi Siswa Taman Kanak- } \\
\text { Kanak (Utami \& } \\
\text { Sukadiyanto, 2014) }\end{array}$ & $\begin{array}{l}\text { Prosedur pengembangan dan } \\
\text { penelitian dalam penelitian ini } \\
\text { mengadaptasikan langkah-langkah } \\
\text { penelitian dan pengembangan } \\
\text { pendidikan yang dikembangkan oleh } \\
\text { Walter Dick \& Lou Carey (Gall et al., } \\
\text { 2003, p. 571). }\end{array}$ & $\begin{array}{l}\text { Hasil penelitian berupa model } \\
\text { pengenalan air bagi siswa TK yang } \\
\text { terdiri dari } 6 \text { permainan, yaitu:... } \\
\text { Model disusun dalam buku pedoman } \\
\text { berjudul "Jelajah Air". }\end{array}$ \\
\hline $\begin{array}{l}\text { Model Pembelajaran } \\
\text { Penjas melalui Permainan } \\
\text { untuk Pembentukan } \\
\text { Karakter Kerja Sama, } \\
\text { Tanggung Jawab dan } \\
\text { Kejujuran Siswa SD } \\
\text { (Rubiyatno \& Suharjana, } \\
\text { 2013) }\end{array}$ & $\begin{array}{l}\text {...menggunakan langkah-langkah } \\
\text { penelitian pengembangan menurut } \\
\text { Borg dan Gall. Menurut (Borg \& Gall, } \\
\text { 1983, p. 775) dalam melakukan } \\
\text { penelitian pengembangan terdapat } 10 \\
\text { langkah yang harus ditempuh sebagai } \\
\text { berikut:... }\end{array}$ & $\begin{array}{l}\text { Hasil penelitian ini berupa buku } \\
\text { panduan aktivitas permainan untuk } \\
\text { pembentukan karakter kerja sama, } \\
\text { tanggung jawab dan kejujuran siswa } \\
\text { sekolah dasar kelas atas, yang } \\
\text { berisikan enam jenis permainan, } \\
\text { yaitu:... }\end{array}$ \\
\hline
\end{tabular}

Contoh model dalam pendidikan jasmani olahraga dan kesehatan misalnya adalah model Health-based Physical Education (HBPE). Model ini memberi kerangka pada bagaimana cara guru memperoleh manfaat kesehatan masyarakat (public health) yang signifikan dari pendidikan jasmani yang mereka ajarkan di kelas. HBPE dapat dianggap sebagai model pedagogis yang penting dalam pendidikan jasmani untuk mendukung siswa mengembangkan gaya hidup sehat sepanjang hayat (Fernandez-Rio, 2016). Model lain yang dikenal luas dalam pendidikan olahraga adalah Teaching Games for Understanding (TGfU).

Penelitian yang bertujuan untuk mengembangkan suatu model, dalam prosedurnya dapat menggunakan metode kajian pustaka terseleksi (selective review) yang berkaitan dengan teori dasar suatu model untuk menghasilkan saran, kritik atau pernyataan posisi peneliti terhadap model tersebut, bukan sebuah produk (contoh: Haerens, Kirk, Cardon, \& Bourdeaudhuij, 2011). Selain itu, pengembangan sebuah model bisa memakan waktu yang lama, mengalami sanggahan, bantahan, kritik, revisi, hingga dapat diterima sebagai bentuk representasi yang paling baik yang mungkin. Model TGfU misalnya, model ini bertahun-tahun dibahas pada Konferensi khusus TGfU yang telah diadakan di New Hampshire (2001), Melbourne, Australia (2003), Hong Kong, Cina (2005), Vancouver, British Columbia, Kanada (2008), dan Loughborough, Inggris (2012). Konferensi ini masih berlanjut. Tidak hanya itu, sebuah model juga memiliki 
komunitas pendukungnya. Dalam mengembangkan model, komunitas TgfU telah menerbitkan jurnal peer-review yang prestisius seperti Journal of Teaching in Physical Education; Sport, Education and Society; Physical Education and Sport Pedagogy; dan European Physical Education Review (Memmert et al., 2015). Penelitian untuk menghasilkan model dalam waktu yang singkat hampir dapat dikatakan mustahil.

Suatu model dapat diposisikan sebagai kerangka yang memberikan basis teori dalam mengembangkan produk pendidikan. Misalnya hasil studi Baran (2014) yang menunjukkan perlunya suatu model pedagogis dan teoretis untuk memandu guru dalam mengembangkan pengalaman belajar melalui media telepon genggam. Produk pendidikan tidak hanya mengacu pada objek material seperti buku teks, media instruksional dan lainnya, namun juga dapat merujuk pada prosedur dan proses seperti metode mengajar. Sebagai contoh, dari model HBPE dapat diteliti program atau aktivitas apa yang dapat dikembangkan sesuai dengan teori dasar model HBPE yang berangkat dari teori motivasi (lihat Fernandez-Rio, 2016).

Berdasarkan argumen tersebut, ketika penelitian dan pengembangan menghasilkan produk, apakah tidak lebih baik menghilangkan kata 'model' pada judulnya? Jika hasil penelitian bukan merupakan sebuah model berwujud skema, grafik atau bentuk lain yang dapat dianggap sebagai model, mungkinkah istilah 'bentuk', 'jenis', atau 'variasi' pembelajaran lebih tepat digunakan? Hal ini mungkin membutuhkan diskusi yang lebih panjang.

\section{Penyajian Referensi pada Prosedur Pengembangan yang Kurang Akurat}

Pada bagian metode penelitian, seluruh artikel yang dianalisis merujuk pada buku "Educational Research: An Introduction" dengan tiga variasi edisi, yaitu edisi ke-4 tahun 1983, edisi ke-7 tahun 2003 dan edisi ke-8 tahun 2007. Edisi pertama buku ini ditulis oleh Walter R. Borg pada 1963 dan diterbitkan oleh David McKay, New York. Pada edisi berikutnya, tahun 1971, muncul nama Meredith D. Gall sebagai penulis kedua. Mengingat Walter R. Borg meninggal dunia pada tahun 1990, maka di edisi setelah tahun tersebut (edisi ke-6 tahun 1996) nama Meredith D. Gall menjadi penulis pertama dan mulai edisi ini pula Joyce P. Gall ikut berkontribusi sebagai penulis. Edisi paling mutakhir dari buku ini adalah edisi ke-8 tahun 2007 dengan susunan penulis Meredith D. Gall,
Joyce P. Gall dan Walter R. Borg. Berdasarkan hasil temuan dalam studi ini, penulisan susunan nama penulis dan edisi buku yang dikutip pada bagian metode kurang dicermati. Dua artikel mencantumkan sumber 'Borg dan Gall' untuk edisi tahun 2003 dan 2007, padahal seharusnya 'Gall, Gall dan Borg'.

Masih dalam penyajian metode, salah satu artikel mengutip buku Metode Penelitian Pendidikan karya Sugiyono edisi 2013. Jika dibandingkan dengan cetakan (bukan edisi) yang lebih baru, misalnya cetakan ke-23 tahun 2016, di dalam buku tersebut penulis buku hanya menulis ulang definisi tanpa memberikan informasi tambahan dan membandingkannya dengan sumber lain. Bahkan, dalam paragraf yang memberikan ilustrasi penelitian dan pengembangan dalam industri (halaman 408), terdapat indikasi kesalahan pengutipan karena tidak mencantumkan tahun dan tidak menunjukkan sumber pertama sebagaimana jelas tercantum dalam catatat kaki buku yang dirujuk (lihat Gall et al., 2003, p. 569). Untuk menghindari ketidakakuratan seperti ini, lebih baik mengutip dari sumber aslinya.

Pada bagian metode, tiga artikel menyebutkan prosedur penelitian dengan (1) 'mengadopsi dari tahapan pengembangan yang dikemukakan oleh Gall, Gall, \& Borg', (2) 'mengadaptasikan langkah-langkah pengembangan pendidikan oleh Borg \& Gall' dan (3) sepuluh langkah pelaksanaan menurut Borg dan Gall. Padahal, di edisi ke-7 "Education Research:..." sangat jelas disebutkan bahwa model yang diajukan adalah model Dick dan Carey, "One of the most widely used models of educational research and development is the systems approach model designed by Walter Dick and Lou Carey" (Gall et al., 2003, p. 570). Dari kelima artikel yang dianalisis, hanya satu yang menyebutkan model Dick dan Carey sebagai basis dalam prosedur pengembangan.

Model Dick dan Carey diakui banyak digunakan dalam penelitian dan pengembangan pendidikan (Setyosari, 2013, p. 276). Model ini dikembangkan dari model ADDIE (Analysis, Design, Development, Implementation, and Evaluation). Model ADDIE sendiri merupakan model generik yang dapat disesuaikan dan dimodifikasi dalam banyak cara (Spector, 2017). Model Dick dan Carey banyak digunakan dalam pengembangan desain instruksional. Hasilnya dinilai membantu dalam meningkatkan pembelajaran (Dick, Carey, \& Carey, 2015). Model ini menyediakan proses langkah demi langkah yang dapat diikuti dengan mudah dan sangat mem- 
bantu peneliti dan perancang pemula dalam memahami rincian prinsip-prinsip dalam desain instruksional (Khalil \& Elkhider, 2016). Model Dick dan Carey telah mengalami revisi dan pengembangan sejak edisi buku pertamanya terbit pada 1978.

Jika pada edisi ke-7, Gall et al. (2003) menampilkan model Dick dan Carey sebagai model desain instruksional yang digunakan dalam prosedur pengembangan, pada edisi ke-4 yang ditulis 20 tahun sebelumnya, Borg dan Gall (1983) mengajukan sepuluh tahapan pengembangan yang dikembangkan oleh timnya untuk mengembangkan mini course. Perbedaan konteks antara pengembangan prosedur dan pengembangan produk pendidikan sebaiknya tidak diabaikan.

Pada penelitian dan pengembangan, temuan dari hasil penelitian digunakan untuk merancang produk atau prosedur baru yang kemudian secara sistematis diuji, dievaluasi, dan disempurnakan hingga memenuhi kriteria efektivitas, kualitas, atau standar tertentu, "...which the findings of the research are used to design new products and procedures..." (Gall et al., 2003, p. 569). Hal yang mungkin perlu didiskusikan adalah: apakah yang dimaksud dengan produk/ prosedur baru belum diketahui sampai adanya hasil penelitian atau peneliti sudah memiliki gambaran tentang produk/ prosedur yang akan dihasilkan kemudian divalidasi melalui penelitian? Pada artikel yang dianalisis, hasil sepertinya sudah ditentukan terlebih dahulu sebagai tujuan penelitian seperti terlihat dalam kalimat pembuka abstrak: "Penelitian ini bertujuan menghasilkan ...". Pandangan lain, bagaimana jika artikel penelitian dan pengembangan mendeskripsikan proses yang telah dijalankan oleh peneliti seperti studi yang dilaporkan oleh Simons et al. (2018) yang menyatakan: "The aim of this study was to describe the development, usability, acceptability, and feasibility of a..." Dengan mendeskripsikan temuan dan proses penelitian yang telah dilakukan, peneliti dapat memberikan informasi berharga bagi pengetahuan (Gall et al., 2003). Pengalaman peneliti menempuh proses penelitian dan pengembangan dapat membantu peneliti selanjutnya, diantaranya dalam menjalankan langkah demi langkah pengembangan agar tidak mengulangi kesalahan yang sama (jika ada) atau memperbaiki prosedur agar lebih efektif.

\section{Prosedur Evaluasi yang Menekankan pada Data Kuantitatif}

Pada bagian metode penelitian, seluruh artikel melaporkan ada dua jenis data yang dikumpulkan, yaitu data kualitatif dan data kuantitatif. Tiga artikel menyebutkan data kualitatif didapatkan dari (1) wawancara, (2) catatan lapangan dan (3) data saran perbaikan draf model awal dan hasil observasi pada pelaksanaan uji coba dengan skala kecil dan besar. Dua artikel lainnya hanya menyebutkan dua sumber data kualitatif, tanpa menggunakan catatan lapangan. Seluruh artikel tidak menjelaskan hasil data kualitatif dalam pembahasan. Hasil dan pembahasan cenderung berisi analisis data kuantitatif. Hasil data kualitatif, terutama wawancara, disampaikan di bagian pendahuluan, namun tidak memuat prosedur pengumpulan data kualitatifnya.

Temuan tersebut mengingatkan pada pandangan reflektif Borg (1987), pakar penelitian dan pengembangan pendidikan yang dirujuk oleh kelima artikel yang dianalisis. Menurutnya, "People who develop instructional materials are for the most part doers. They are people who perceive gaps or deficiencies in the instructional process and are strongly motivated to fill in these gaps and overcome these deficiencies". Penelitian dan pengembangan pendidikan banyak dilatarbelakangi oleh masalah yang dipersepsi oleh peneliti dan keinginan untuk mengatasi masalah tersebut. Hal ini tidak lepas dari karakteristiknya sebagai penelitian terapan. Sepertinya pandangan Borg ini masih berlaku sampai sekarang.

Kembali pada definisi penelitian dan pengembangan, prosedur perlakuan yang dianggap baku pada produk yang dikembangkan dari penelitian adalah adanya uji lapangan secara sistematis, evaluasi dan perbaikan (systematically field-tested, evaluated, and refined). Teknik evaluasi, dengan demikian, memainkan peranan yang penting dalam penelitian dan pengembangan. Dalam proses penelitian dan pengembangan terdapat dua pokok aktivitas, yaitu mengembangkan dan memvalidasi (Setyosari, 2013). Evaluasi pendidikan berkaitan erat dengan penelitian dan pengembangan pendidikan, "The field of educational evaluation is closely related to educational research and development. Evaluation technique play major role in $R \& D, \ldots$ (Borg \& Gall, 1983, p. 773). Pada edisi 1983, penelitian dan pengembangan pendidikan dibahas dalam satu bab khusus sementara di edisi 2003, penelitian dan pengembangan pendidikan dimasukkkan dalam 
pembahasan penelitian evaluasi. Hal ini menunjukkan eratnya evaluasi dan pengembangan.

Edisi 1983 buku "Educational

Research:..." menjelaskan proses pengembangan yang dialami oleh penulisnya, sedangkan pada edisi 2003 "sepuluh tahapan pegembang-an" diganti dengan model desain instruksional yang dikembangkan oleh Dick dan Carey dengan menambahkan formulasi dari Schriven pada evaluasi formatif dan sumatifnya. Evaluasi formatif dilakukan sepanjang proses pengembangan. Hasil evaluasi digunakan sebagai basis untuk meningkatkan efektivitas produk, dan dalam situasi tertentu temuan dalam evaluasi formatif dapat berujung pada keputusan untuk membatalkan tahapan pengembangan selanjutnya (Gall et al., 2003, p. 570). Prosedur ini jarang ditemui pada laporan hasil penelitian dan pengembangan.

Dalam mendesain sebuah pembelajaran, Durak dan Ataizi (2016) menganjurkan agar menjaga kesinambungan antara pengembangan dan langkah evaluasinya. Untuk setiap masalah yang dialami oleh peserta didik, proses/langkah pengembangan harus ditinjau kembali. Dalam hal ini, proses evaluasi formatif harus dituntaskan. Dick dan Carey merekomendasikan tiga tingkat evaluasi formatif. Pertama, mencoba prototipe material secara individu (one on one) yaitu evaluator bekerja dengan satu orang siswa. Tingkat kedua, ujicoba terhadap kelompok kecil yang terdiri dari enam sampai delapan siswa. Ketiga, uji coba lapangan yang melibatkan seluruh anggota kelas, yang masih termasuk kecil. Bagian yang sering luput dari perhatian adalah pada penjelasan berikutnya, "This phase of evaluation relies heavily on qualitative methods, for example, interviewing and observation by the developer" (Gall et al., 2003, p. 572). Sesuai dengan saran pencetus model pengembangannya, sebaiknya fase evaluasi formatif menekankan pada metode kualitatif seperti wawancara dan observasi oleh peneliti/pengembang. Temuan dalam studi ini menunjukkan evaluasi lebih banyak dilakukan secara kuantitatif dengan bertumpu pada data-data statistik yang diperoleh dari angket dan rubrik penilaian.

Kurangnya analisis data kualitatif membuat peneliti/pengembang kehilangan kesempatan untuk melakukan refleksi atas penelitian yang dilakukannya. Penekanan yang kuat pada apa yang dianggap sebagai objektivitas, dengan mengandalkan penilaian ahli, pada satu sisi justru mengkerdilkan potensi penelitian dan pengembangan sebagai penelitian terapan untuk mengisi celah antara penelitian pendidikan dan praktiknya. Hal ini sudah diperingatkan oleh (Legrand, 1969) setengah abad yang lalu, “...applied educational research as we understand it does not mean merely recording the external aspect of a situation quantitatively and demonstrating how methods work. Penelitian terapan tidak sekedar merekam aspek eksternal dari suatu situasi secara kuantitatif dan mendemonstrasikan bagaimana metode bekerja.

\section{SIMPULAN}

Berdasarkan temuan dalam studi ini, penelitian dan pengembangan merupakan jenis penelitian yang paling banyak dilakukan dan dilaporkan di Jurnal Keolahragaan. Jumlahnya mendekati setengah dari keseluruhan artikel yang telah diterbitkan di jurnal tersebut. Hasil ini membuktikan asumsi awal penelitian dan menunjukkan minat yang besar dari para peneliti di bidang ilmu keolahragaan pada penelitian dan pengembangan. Pengembangan yang dilakukan dapat digolongkan ke dalam dua kategori: pendidikan dan non-pendidikan yang dibedakan berdasarkan subjek penelitiannya. Pengembangan model pembelajaran merupakan jenis pengembangan pendidikan yang paling banyak dilakukan, disusul pengembangan model permainan atau aktivitas, pengembangan media pembelajaran, pengembangan modul pembelajaran dan pengembangan alat untuk pembelajaran. Analisis pada sampel artikel pengembangan model pembelajaran menghasilkan pembahasan tema yang meliputi: kerancuan dalam penggunaan istilah 'model', kekurangakuratan dalam menyajikan referensi yang berkaitan dengan prosedur pengembangan dan prosedur evaluasi yang cenderung menampilkan analisis data-data kuantitatif. Secara umum isu-isu yang telah dibahas dalam studi ini diharapkan menjadi pemantik diskusi lebih lanjut bagi para peneliti yang memiliki ketertarikan pada jenis penelitian dan pengembangan.

Studi ini mengalami keterbatasan pada metode yang digunakan. Studi dokumen yang umumnya digunakan sebagai metode yang berdampingan dengan metode pengumpulan data lain dalam penelitian kualitatif, dalam penelitian ini digunakan sebagai metode tunggal. Area pengumpulan datanya pun dipersempit pada sebuah media penerbitan ilmiah berkala. Hal ini dilakukan tidak lepas dari tujuan yang memang dirancang spesifik untuk melihat dan menganalisis dokumen dari satu media saja yaitu Jurnal Keolahragaan. 


\section{DAFTAR PUSTAKA}

Aisyah, E. N., \& Mahanani, P. (2017). Pelatihan menulisan artikel ilmiah bagi guru sekolah dasar dan taman kanak-kanak Kecamatan Tajinan Kabupaten Malang. Abdimas Pedagogi: Jurnal Ilmiah Pengabdian Kepada Masyarakat, 1(1). Retrieved from http://journal2.um.ac.id/index.php/pedago gi/article/view/1947

Baran, E. (2014). A review of research on mobile learning in teacher education. Educational Technology \& Society, 17(4), 17-32. https://doi.org/10.1007/s10639-011-91828

Bokulich, A. (2011). How scientific models can explain. Synthese, 180, 33-45. https://doi.org/10.1007/s11229-009-95651

Borg, W. R. (1987). The educational R \& D process: some insights. The Journal of Experimental Education, 55(4), 181-188. https://doi.org/10.1080/00220973.1987.10 806452

Borg, W. R., \& Gall, M. D. (1983). Educational research: An introduction. New York: Longman.

Cohen, L., Manion, L., \& Morrison, K. (2007). Research methods in education (6th ed.). Abingdon: Routledge. https://doi.org/10.1080/19415257.2011.64 3130

Darmalaksana, W. (2017). Panduan publikasi ilmiah: Perangkat aplikasi, standar penulisan dan etika kepengarangan. Jurnal Riset Dan Inovasi, 2, 24-42.

Dick, W., Carey, L., \& Carey, J. O. (2015). The systematic design of instruction (8th ed.). Upper Saddle River, New Jersey: Pearson.

Durak, G., \& Ataizi, M. (2016). The ABC's of online course design according to Addie model. Universal Journal of Educational Research, 4(9), 2084-2091. https://doi.org/10.13189/ujer.2016.040920

Fernandez-Rio, J. (2016). Health-based physical education: a model for educators. Journal of Physical Education, Recreation \& Dance, 87(8), 5-7. https://doi.org/10.1080/07303084.2016.12 17123

Fitri, A. H., \& Winarni, S. (2016). Model pembelajaran integratif penjasorkes materi atletik dengan pendidikan IPA materi
Biologi untuk siswa SMP. Jurnal Keolahragaan, $\quad 4(1), \quad 1$. https://doi.org/10.21831/jk.v4i1.8108

Gall, M. D. (1991). In memoriam: Walter R. Borg. The Journal of Experimental Education, 59(2), 107-109.

Gall, M. D., Gall, J. P., \& Borg, W. R. (2003). Educational research: an introduction (7th ed.). Boston, MA: Allyn and Bacon.

Gall, M. D., Gall, J. P., \& Borg, W. R. (2007a). An introduction to educational design research. East. Retrieved from www.slo.nl/organisatie/international/publi cations

Gall, M. D., Gall, J. P., \& Borg, W. R. (2007b). Educational research: An introduction. Boston: Pearson/Allyn \& Bacon.

Haerens, L., Kirk, D., Cardon, G., \& Bourdeaudhuij, I. De. (2011). The development of a pedagogical model for Health-Based Physical Education. Quest, 63(3), 321-338.

Haryati, S. (2012). Research and development (R\&D) sebagai salah satu model penelitian dalam bidang pendidikan. Majalah Ilmiah Dinamika, 37(1), 11-26.

Kementerian Pendidikan dan Kebudayaan. (n.d.). Data Referensi Pendidikan.

Khalil, M. K., \& Elkhider, I. A. (2016). Applying learning theories and instructional design models for effective instruction. Advances in Physiology Education, 40, 147-156. https://doi.org/10.1152/advan.00138.2015

Legrand, L. (1969). Educational research and development. Western European Education, $\quad 1(4), \quad 42-54$. https://doi.org/10.2753/eue10564934010442

Memmert, D., Hillmann, W., Huttermann, S., Klein-Soetebier, T., Konig, S., Nopp, S., ... Griffin, L. (2015). Top 10 research questions related to teaching games for understanding. Research Quarterly for Exercise and Sport, 86(4), 347-359. https://doi.org/10.1080/02701367.2015.10 87294

Moleong, L. (2007). Metodologi penelitian kualitatif. Bandung: Remaja Rosdakarya.

Nilamsari, N. (2014). Memahami studi dokumen dalam penelitian kualitatif. Wacana: Jurnal Ilmiah Ilmu Komunikasi, 13(2), 177-181. 
https://doi.org/10.32509/wacana.v13i2.14 3

Noor, I. H. (2010). Penelitian dan pengabdian masyarakat pada perguruan tinggi. Jurnal Pendidikan Dan Kebudayaan, 16(3), 285297.

https://doi.org/10.24832\%2Fjpnk.v16i3.4 62

Purwanto, D. D., \& Suharjana, S. (2017). Pengembangan model pembelajaran pengenalan teknik dasar tenis meja untuk siswa SD kelas atas. Jurnal Keolahragaan, $5(2)$, 133. https://doi.org/10.21831/jk.v5i2.6419

Retnowati, T. H., Mardapi, D., \& Kartowagiran, B. (2018). Kinerja dosen di bidang penelitian dan publikasi ilmiah. Jurnal Akuntabilitas Manajemen Pendidikan, 6(2), 215-225. https://doi.org/10.21831/amp.v6i2.21524

Rubiyatno, R., \& Suharjana, S. (2013). Model pembelajaran penjas melalui permainan untuk pembentukan karakter kerja sama, tanggung jawab dan kejujuran siswa SD. Jurnal Keolahragaan, 1(2), 166-175. https://doi.org/10.21831/jk.v1i2.2572

Setyosari, P. (2013). Metode penelitian pendidikan dan pengembangan (4th ed.). Jakarta: Prenadamedia Group.

Simons, D., De Bourdeaudhuij, I., Clarys, P., De Cocker, K., Vandelanotte, C., \& Deforche, B. (2018). A smartphone app to promote an active lifestyle in lower-educated working young adults: development, usability, acceptability, and feasibility study. JMIR Mhealth and Uhealth, 6(2), 118. https://doi.org/10.2196/mhealth.8287

Spector, J. M. (2017). Reflections on educational technology research and development. Educational Technology Research and Development, 65, 1415-1423. https://doi.org/10.1007/s11423-017-9545- y

Sutarti, T., \& Irawan, E. (2017). Kiat sukses meraih hibah penelitian pengembangan. Yogyakarta: Deepublish.

Tegeh, I. M., Jampel, I. N., \& Pudjawan, K. (2015). Pengembangan buku ajar model penelitian pengembangan dengan model ADDIE. In Seminar Nasional Riset Inovatif (Vol. 3).

Utami, N. S., \& Sukadiyanto, S. (2014). Model pengenalan air bagi siswa taman kanakkanak. Jurnal Keolahragaan, 2(2), 204215. https://doi.org/10.21831/jk.v2i2.2626

Vanderlinde, R., \& van Braak, J. (2010). The gap between educational research and practice: Views of teachers, school leaders, intermediaries and researchers. British Educational Research Journal, 36(2), 299-316.

https://doi.org/10.1080/014119209029192 57

Walter, E. (2008). Cambridge advanced learner's dictionary. Cambridge University Press.

Wibawa, K. A., \& Sugiyanto, F. X. (2015). Gerak multilateral melalui permainan bola besar untuk anak SD kelas bawah. Jurnal Keolahragaan, 3(2), 194-207. https://doi.org/10.21831/jk.v3i2.6244

Wijayanti, K. E., \& Wibowo, R. (2017). Pembelajaran pendidikan kesehatan berbasis riset: Ulasan dan implementasinya di Indonesia. Jurnal Pendidikan Jasmani Dan Olahraga, 9(2), 14-20. https://doi.org/10.17509/jpjo.v2i2.8174

Winarno, M. E. (2018). Mendorong pengembangan literasi keolahragaan nasional. In Seminar Nasional Pendidikan Jasmani dan Olahraga (pp. 7-14). Jombang: STKIP PGRI Jombang. 